
Not for reproduction, distribution or commercial use.

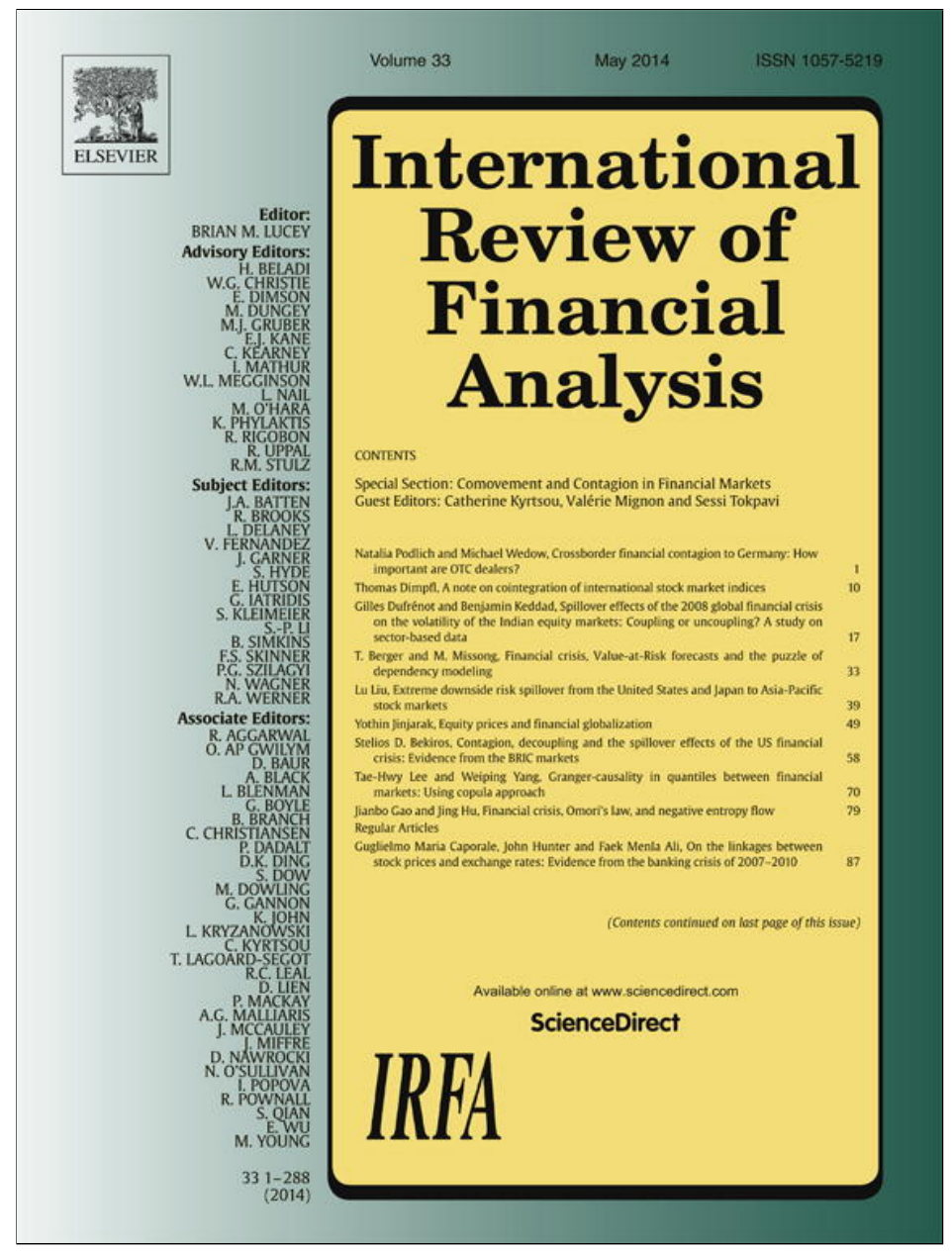

This article appeared in a journal published by Elsevier. The attached copy is furnished to the author for internal non-commercial research and education use, including for instruction at the authors institution and sharing with colleagues.

Other uses, including reproduction and distribution, or selling or licensing copies, or posting to personal, institutional or third party websites are prohibited.

In most cases authors are permitted to post their version of the article (e.g. in Word or Tex form) to their personal website or institutional repository. Authors requiring further information regarding Elsevier's archiving and manuscript policies are encouraged to visit: 


\title{
Equity prices and financial globalization
}

\author{
Yothin Jinjarak * \\ DeFiMS, SOAS, University of London, 534 College Buildings, Russell Square, Thornhaugh Street, London WC1H 0XG, United Kingdom
}

\section{A R T I C L E I N F O}

Available online 16 September 2013

\section{JEL classification:}

F42

E44

E52

G15

Keywords:

Asset prices

Economic integration

Monetary policy

Oil prices

\begin{abstract}
A B S T R A C T
This paper examines the association between equity returns, economic shocks, and economic integration. The empirical findings show that oil prices and U.S. Federal Reserve funds rates are associated with negative responses of international equity returns, of which a simple asset-pricing model is capable of explaining the international differences. Using vector autoregressions, we find that the effects of global economic shocks operate through the current excess returns of equity prices. Empirically, trade integration increases the responses of international equity returns to oil prices, while finance integration increases the responses of equity returns to Federal Reserve funds rates across countries.
\end{abstract}

(c) 2013 Elsevier Inc. All rights reserved.

\section{Introduction}

The objective of this paper is to study the empirical response, together with its determinants, of international equity returns to global economic shocks. Using international data of equity prices, our analysis proceeds in two stages. First, we estimate the responses of equity prices to oil prices and U.S. Federal Reserve funds rates. Second, the estimated response of equity prices is further examined into its components and then its association with economic integration is studied. The sample covers years 1989-2006, a period of relative macroeconomic and financial stability, chosen in order to understand discernible patterns in the data across major economies.

This study cuts across several strands of finance and economic literature. In an international finance context, news about the global economy, i.e. energy markets and Federal Reserve policy, may generate global shocks on the equity investment. Empirical regularities suggest (i) that a tightening of the Federal Reserve policy is negatively associated with equity returns (Bernanke and Kuttner (2005), Chen (2007), Patelis (1997), Rigobon and Sack (2003, 2004), Thorbecke (1997), Ehrmann and Fratzscher (2004, 2006), and Conover, Jensen, and Johnson (1999)); (ii) that national equity markets are positively correlated in responding to macroeconomic and global factors (Albuquerque and Vega (2007), Andersen, Bollerslev, Diebold, and Vega (2007), Ammer and Wongswan (2007), and Craine and Martin (2008)); and (iii) that an observed innovation in current excess equity return can

\footnotetext{
* Tel.: +44 207898 4352; fax: +442078984829.

E-mail address: yj5@soas.ac.uk.
}

be decomposed into the discounted sum of return revisions in future dividends, real interest rates, expected future excess equity returns and real exchange rates (Ammer \& Mei, 1996). We contribute to this stand of the literature by studying the empirical components of equity prices and their informativeness, in order to understand the role of economic shocks and economic integration on the international equity markets.

In a macroeconomics context, the response of asset prices to exogenous shocks has considerable implications on the economic fluctuations (Bernanke, Gertler, and Watson (1997, 2004), Carlstrom and Fuerst (2006), Hamilton and Herrera (2004), and Leduc and Sill (2004)). On the oil prices, Jones and Kaul (1996) find that the responses of cash flows and dividends account for the response of the U.S. and Canadian equity prices to oil shocks; Kilian and Park (2009) find that the U.S. equity market respond negatively to oil-market specific demand shocks (e.g. precautionary demand), but positively to aggregate demand shocks at the global level. On the Federal Reserve funds rates, Bernanke and Kuttner (2005) find that expected returns account for the majority of the response of U.S. equity markets to Federal Reserve funds rates; Wongswan (2009) find that fifteen foreign equity indices respond to U.S. monetary policy surprises. We contribute to this strand of the literature by studying the effects of both oil prices and Federal Reserve funds rates on the fluctuations of asset prices internationally. ${ }^{1}$

\footnotetext{
${ }^{1}$ In addition, note that movements in equity prices may capture expectation about future economic growth at home and abroad; there is some evidence that the innovation in equity prices is contemporaneously orthogonal to total factor productivity, but highly correlated with the shock explaining long-run movements in the productivity (Beaudry \& Portier, 2006).
} 
Table 1

Correlations of crude oil prices, Federal funds rates, and international equity returns. Monthly data spanning May 1989-December 2006. The prices of crude oil are in dollars per barre (source: Energy Information Administration). The Federal funds target rates are in percentage points (source: Datastream). Equity returns are value-weighted in U.S. dollars, based on MSCI portfolios. EAFE is an abbreviation for Europe, Australia, and the Far East. Europe includes Austria, Belgium, Switzerland, Germany, Denmark, Spain, France, United Kingdom, Ireland, Italy, and the Netherlands. Scandinavia includes Finland, Norway, and Sweden. Asia and Pacific includes Australia, Hong Kong, Japan, Malaysia, New Zealand, and Singapore. Market capitalization (percent of world) is based on world development indicators. Average holding by U.S. investors (percent of country's capitalization) is based on U.S. TIC System data.

\begin{tabular}{|c|c|c|c|c|}
\hline Regional markets & EAFE & Europe & Scandinavia & Asia \& Pacific \\
\hline $\begin{array}{l}\text { Capitalization/world (\%) } \\
\text { (Holding by U.S. investors \% } \\
\text { of capitalization) }\end{array}$ & $\begin{array}{c}41.130 \\
(12.191)\end{array}$ & $\begin{array}{c}23.290 \\
(13.469)\end{array}$ & $\begin{array}{c}1.850 \\
(14.250)\end{array}$ & $\begin{array}{l}15.990 \\
(8.817)\end{array}$ \\
\hline \multicolumn{5}{|c|}{ Correlation of excess equity returns with global economic shocks: } \\
\hline Oil prices & -0.112 & -0.138 & -0.078 & -0.042 \\
\hline Funds rates & -0.053 & -0.085 & -0.044 & -0.037 \\
\hline
\end{tabular}

In the context of international economics, the empirical responses of international equity returns to global shocks help understanding the risk sharing across markets. By and large, previous studies suggest that the larger the volume of trade and financial integration between countries, the higher the correlation of equity returns (Coeurdacier Kollmann, and Martin (2007), Aviat and Coeurdacier (2007), Portes and Rey (2005), Forbes and Chinn (2004), and Imbs (2004)). We contribute to this strand of the literature by accounting for the effects of trade and finance integration on the risk diversification and international portfolio investment, focusing on the responses of global equity returns to exogenous movements of oil prices and Federal Reserve funds rates across countries.

The rest of this paper is organized as follows. The next section discusses the data and preliminary analysis of international equity returns, oil prices, and Federal Reserve funds rates, and studies the association between equity returns and global economic shocks in an international asset-pricing framework. To gain further insights, Section 3 reports the decomposition of equity returns into the detailed responses to oil prices and Federal Reserve funds rates, and examines their relationship with trade and finance integration. The conclusion is in Section 4.

\section{Data and preliminary analysis}

The data on international equity returns are derived from MSCI valueweighted country returns in US dollars, based on Kenneth French's database. We use the monthly data, spanning May 1989 to December 2006 and covering more than $80 \%$ of the global market capitalization. While some previous studies use higher frequency data, we focus here on the monthly frequency as we are interested in the average response of equity returns and its association with economic integration. Using instead the daily or weekly data has the benefits of capturing the real-time movement of equity returns, but this involves more noises and price changes that might be reversed quickly over a course of the month due to a garden variety of factors. We consider two economic shocks, the oil prices and the Federal Reserve funds rates. For the oil prices, we use the prices of crude oil in dollar per barrel, based on the Energy Information Administration. For the Federal Reserve funds target rates, the series are taken from Datastream.

Table 1 provides descriptive statistics of excess equity returns (over the Treasury bill rates), studying their correlation with the changes in the oil prices and the Federal Reserve funds rates across geographic regions of equity investment. As shown in the table, both the increase of oil prices and the increase of Federal Reserve funds rates are associated with negative excess equity returns. To proceed, we will next disaggregate the changes of oil prices and Federal funds rates into their expected and unexpected components, and examine their association with international equity returns in a simple asset-pricing model. The responses of excess equity returns to the global shocks will then be decomposed into news (revisions in expectation) about dividend, interest rate, future excess returns, and real exchange rates. In the final step, we will estimate how the empirical responses of equity returns are attributable to integration via trade and finance across countries.

\subsection{Global Economic shocks: oil prices and Federal Reserve funds rates}

Since the financial markets are forward looking, only the unexpected component of the changes in oil prices and Federal Reserve funds rates may influence the innovation in excess equity returns. To measure the unexpected, or surprise, component of these two global economic shocks, we follow the methodology of Kuttner (2001) and Bernanke and Kuttner (2005) in constructing the expected and unexpected components, first on the Federal funds rates, then on the oil prices. Using the futures data, the unexpected component of Federal funds rates $(i$, in percentage points) and oil prices ( $o$, in dollars per barrel) is constructed as

$\bar{\Delta} s_{t}^{u}=\frac{1}{D} \sum_{d=1}^{D} s_{t, d}-f_{t-1, D}^{1}$

where $s=\{o, i\} ; s_{t, d}$ is the rate on day $d$ of month $t$, and $f_{t-1, D}^{1}$ is the rate of the 1-month futures contract on the last (Dth) day of month $t-1$. The notation $\bar{\Delta}$ is used to distinguish this from the first-difference operator. The expected component is constructed as

$\bar{\Delta} s_{t}^{e}=f_{t-1, D}^{1}-s_{t-1, D}$.

$\bar{\Delta} s_{t}^{e}+\bar{\Delta} s_{t}^{u}=\bar{\Delta} s_{t}$ is the average in month- $t$ minus the value on the last day of month $t-1$. $^{2}$ Based on this configuration, from May 1989 to December 2006 the standard deviation of oil prices is about 1.8 dollars per barrel, with the unexpected components making up most of the changes in oil prices. For the funds rates, the standard deviation is .22 and we find that the expected component is slightly more important than the unexpected component. ${ }^{3}$

Note that on possible feedbacks between funds rates and oil prices, if endogeneity is the issue, then the effects of oil prices on the equity returns would be larger by endogenous monetary responses. However, much of the concern in the literature on the oil-monetary policy endogeneity revolved around the earlier episodes (early 80s and before) that are outside the sample period in this paper (1989-2006). More importantly, as shown recently by Kilian and Park (2009), the VAR model of federal funds rates and oil prices has provided no supportive evidence that the Federal Reserve changes interest rates in response to oil prices. ${ }^{4}$

The measurements of economic shocks being used here are admittedly not perfect, but objective and repeatable at a monthly frequency with readily available futures data on crude oil prices and Federal funds rates. Three measurement issues are in order. First, we make no distinction between target surprises and path surprises of oil prices

\footnotetext{
2 Following Bernanke and Kuttner (2005) we exclude the September 17, 2001 observation for the Federal funds rate as it was the rate cut on the first trading day after the September 11 event

${ }^{3}$ Before 1994, the Federal Reserve made no public announcement of its target for the Federal funds rate following the FOMC meetings at which the target was determined; as a result, financial markets had to infer the target rate from the subsequent open market operations. From February 1994 onwards, the Federal Reserve announces all the changes in its target rate, the action which eliminates uncertainty about the date of rate changes and influences the path of financial variables [Davig and Gerlach (2006), Woodford (2005)]. For this reason, existing studies on the response of financial markets to Federal Reserve policy use the year 1994 as a cutoff.

${ }^{4}$ Although the central banks may generally not want to respond to movements in asset prices (Bernanke \& Gertler, 2001), it is also possible that central banks' response to movements in equity prices driven by relative productivity shocks may yield some price stability benefits (e.g.Di Giorgio \& Nistico, 2007).
} 
and funds rates. ${ }^{5}$ Second, there is no straightforward way to measure the unexpected component of monetary policy effects due to the local authorities because there is no related futures contract similar to the Federal funds futures. ${ }^{6}$ Third, the responses of equity returns to oil prices and funds rates may be asymmetric and cannot be accounted by the present methodology.

\subsection{International asset-pricing model}

As a preliminary analysis, we apply the least-squares estimation to measure the responses of excess equity returns to oil prices and funds rates. The dependent variable is the MSCI (Fama-French) valueweighted dollar excess return $\left(e_{t}\right)$, the explanatory variables are the expected $\left(s_{t}^{e}\right)$ and the unexpected $\left(s_{t}^{u}\right)$ components of oil prices and funds rates:

$e_{t}=a+B^{e} \bar{\Delta} s_{t}^{e}+B^{u} \bar{\Delta} s_{t}^{u}+\varepsilon_{t}$,

where $s=[0, i]^{\prime}$ and $\varepsilon_{t}$ is the error term. We also control for sample instability before and after 1994 using the interaction terms of the explanatory variables and a dummy variable that is equal to one for the period after February 1994 onwards. Based on the estimates, an international CAPM model would explain for each country all the expected returns by the slopes on the world market return. Fama and French (1998) find that an international two-factor (one-state variable) ICAPM model does better than the international CAPM in explaining the high average returns on the country value portfolio. They point out that the global high and low book-to-market (B/M) portfolios are two-factor multifactor-minimum-variance (MMV) portfolios, so the difference between the high- and low B/M portfolio returns can be the second explanatory return in a one-state-variable ICAPM. To check whether the observed reaction is proportional to the countries' betas, we first obtain country betas from a regression of excess equity return for country $i, e_{i, t}$, on the global market excess return, $e_{w, t}^{m k t}$, and the difference between returns of the global high- and low portfolios, $e_{w, t}^{h-l}$ :

$e_{i, t}=\alpha+\beta_{i}^{1} e_{w, t}^{m}+\beta_{i}^{2} e_{w, t}^{h-l}+\nu_{i, t}$.

Then, it follows that the country response implied by the two-factor ICAPM is

$\hat{b}_{i}^{u}=\hat{\beta}_{i}^{1}\left(\hat{b}_{w}^{m}\right)+\hat{\beta}_{i}^{2}\left(\hat{b}_{w}^{h-l}\right)$,

where $\hat{b}_{i}^{u}$ is the estimated response of the value-weighted excess equity return of country $i$ to the surprise (unexpected component of oil prices and funds rates) implied by the two-factor ICAPM; $w \in$ the global

\footnotetext{
${ }^{5}$ While beyond the scope of this paper, on the target and path surprises, see Cavallo and Wu (2006), Wu and McCallum (2005), Gurkaynak, Sack, and Swanson (2005), and Romer and Romer (2004). Piazzesi and SwansonPiazzesi and Swanson (2008) suggests that the measures of Fed policy shocks require some adjustment if there exists risk premia in the Federal funds futures; the Fed policy shocks based on the one-day change in the funds futures around FOMC announcements pioneered by Kuttner (2001), and being applied in the present analysis, are robust to the presence of risk premia. Similarly, prices of crude oil futures may convey useful information regarding shifts in market expectations about future demand and supply conditions, but the prices of oil futures would be expected to forecast spot prices only under certain restrictive conditions; how well these forecasts work in practice depends on the properties of risk premium (Alquist \& Kilian, 2010).

${ }^{6}$ On the monetary interdependence, see Bergin and Jorda (2004), Scotti (2006), Cooley and Quadrini (2003), Ehrmann and Fratzscher (2007), Gosselin, Lotz, and Wyplosz (2007), Pappa (2004), and Taylor (2007). On the role of local authority's monetary policy, Andersson (2007) finds in the European markets sample a muted reaction of financial markets to the local monetary policy decisions, comparing to a more significant reaction of the U.S. equity markets to the Fed policy; see also Conover et al. (1999) and Craine and Martin (2008).

7 Hamilton (2003) finds that the effects on GDP growth of oil price increases are more important than those of oil price decreases. Ehrmann and Fratzscher (2006) find that none of the specific characteristics of the Fed's interest-rate decisions (i.e. direction, size, and non-action) are statistically significant on the reaction of global equity-market indices.
}

portfolio, regional portfolios\} denotes the world market return; $\hat{b}_{w}^{m}$ denotes the estimated reaction of the world market portfolio; $\hat{b}_{w}^{h-l}$ denotes the estimated response of the difference between returns of the world high- and low value portfolios. The estimation is done for the global equity returns using all four alternative measures of value-growth premia: book-to-market, cash flow-to-price, dividend-to-price, and earnings-toprice. For the world market return in Eq. (4) we use the global portfolio, and alternatively the corresponding regional portfolios as the equity markets tend to be more highly correlated with markets in the same region (Forbes \& Rigobon, 2002).

Fig. 1 plots the estimated responses to the surprise component of, respectively, oil prices and funds rates from Eq. (3) against the implied responses, $\hat{b}_{i}^{u}$, from Eq. (5) using the global portfolio (upper panel) and the regional portfolios (lower panel). To allow for a different pattern in the sample after February 1994, the left panel depicts the plot for the whole sample and the right panel for the post 1994 sample. Also plotted is the 45-degree line that the scatterplots would lie on if the two-factor ICAPM perfectly explained the responses across countries. As shown, the regional-ICAPM does reasonably well in explaining the responses of equity returns to oil prices and funds rates. Although the fit is not perfect, the scatterplots line up along the 45-degree line. The regional-ICAPM thus provides a parsimonious way to summarize the general patterns in the responses of international equity returns to unexpected movements of oil prices and funds rates in the data.

\section{Empirical analysis of equity returns, global shocks, and economic integration}

\subsection{Variance decomposition of equity returns}

This section formally accounts for potential factors driving the observed responses of the international equity returns to oil prices and funds rates. Essentially, the innovations (movements) in current excess equity returns are associated with the revisions in expectation or news on three components: expected future dividends, future expected real interest rates used to discount those dividends, expected excess returns (i.e. the equity premium), and, in the case of investment in international equities, the real exchange rates. Following the variance decomposition of Campbell and Ammer (1993), and Ammer and Mei (1996), we first dissect the innovation in the U.S. excess equity returns into news about future dividends, interest rates, and future excess returns, then use VAR to estimate proxies for revisions in expectation. The innovation in U.S. excess equity return is

$\widetilde{e}_{t+1}=\left(E_{t+1}-E_{t}\right)\left\{\sum_{j=0}^{\infty} \rho^{j} \Delta d_{t+1+j}-\sum_{j=0}^{\infty} \rho^{j} \Delta r_{t+1+j}-\sum_{j=0}^{\infty} \rho^{j} \Delta e_{t+1+j}\right\}$,

where $r$ is the one-period Treasury bill return and $d$ is the dividend paid. A tilde $(\sim)$ superscript represents an innovation in a variable, and a delta $\Delta$ denotes a first difference. $E_{t}$ denotes expectation formed at the end of period $t, E_{t+1}-E_{t}$ is the revision in expectations given new information arrived during period $t+1 . \rho$, a constant of linearization, is a steady-state ratio of the equity price to the price plus dividend. ${ }^{8}$ The decomposition can be rewritten as

$\tilde{e}_{t+1}=\widetilde{e}_{d, t+1}-\widetilde{e}_{r, t+1}-\tilde{e}_{e, t+1}$,

where $\widetilde{e}_{t+1}$ is the excess equity return innovation. $\widetilde{e}_{d, t+1}$ denotes news about future dividends; $\widetilde{e}_{r, t+1}$ news about interest rates; and $\widetilde{e}_{e, t+1}$ news about expected future excess return (equity risk premia). The intuition for the signs is the following. News of smaller dividend growth,

\footnotetext{
${ }^{8}$ Following Campbell and Ammer (1993), this is set to 0.9962.
} 
A

a) Using Global Portfolios in ICAPM
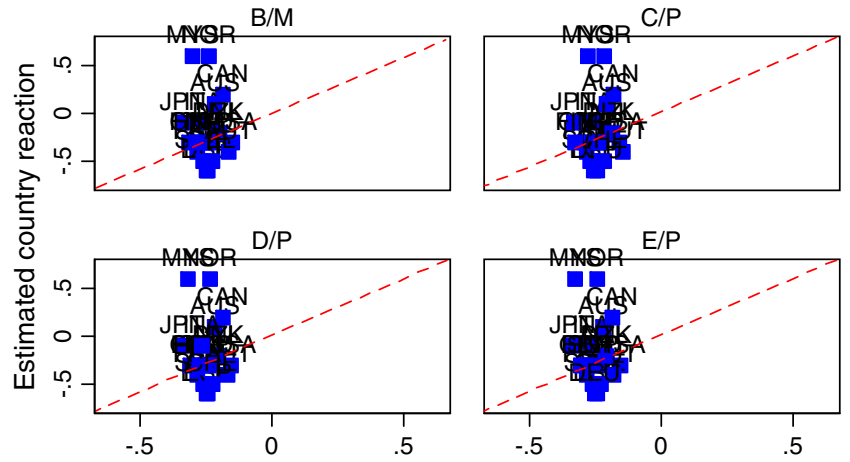

c) Using Regional Portfolios in ICAPM
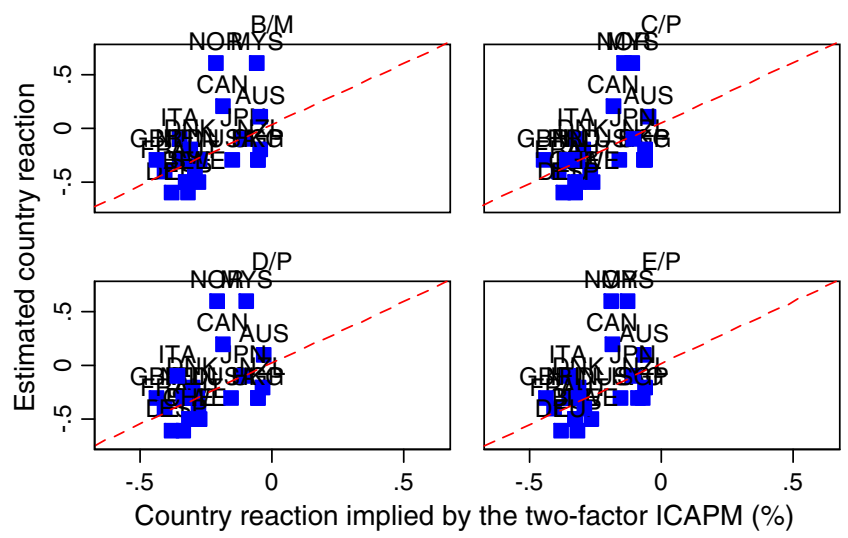

B

May 1989 - December 2006

a) Using Global Portfolios in ICAPM
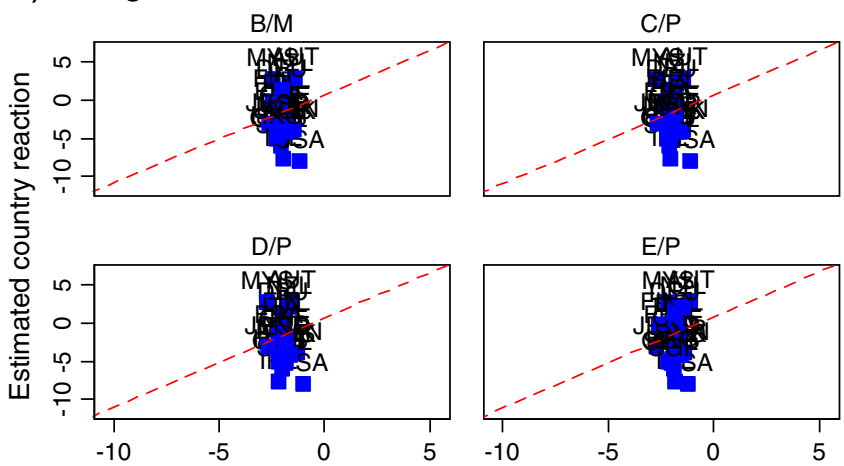

C) Using Regional Portfolios in ICAPM

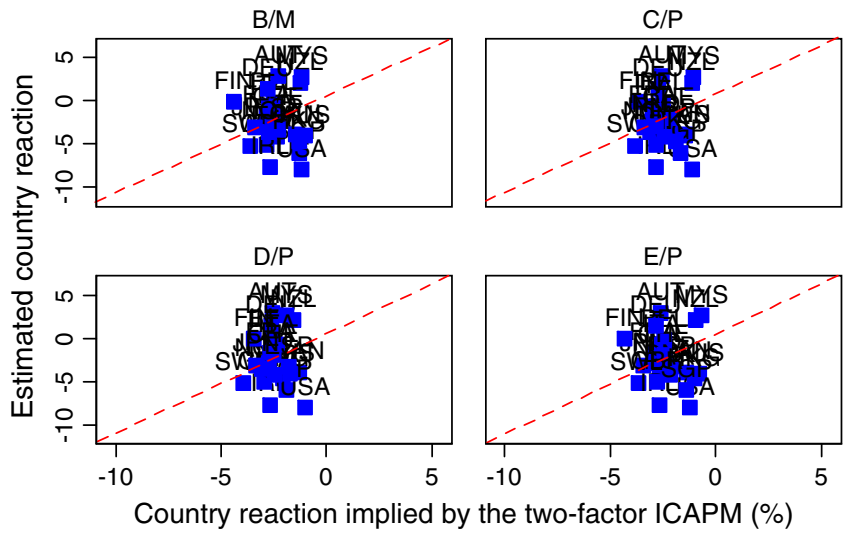

February 1994 - December 2006

b) Using Global Portfolios in ICAPM
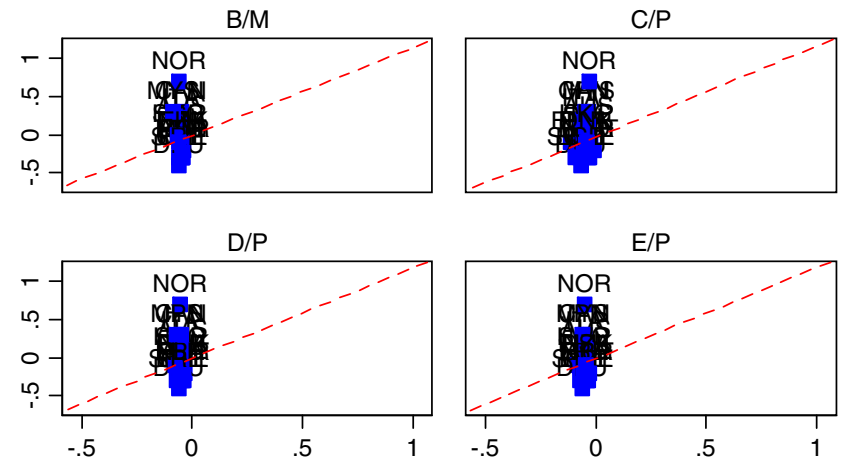

d) Using Regional Portfolios in ICAPM
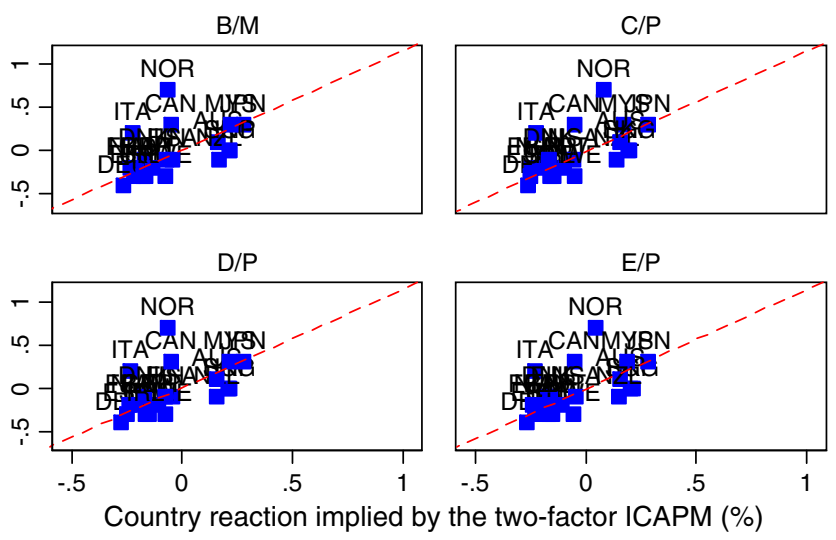

February 1994 - December 2006

b) Using Global Portfolios in ICAPM
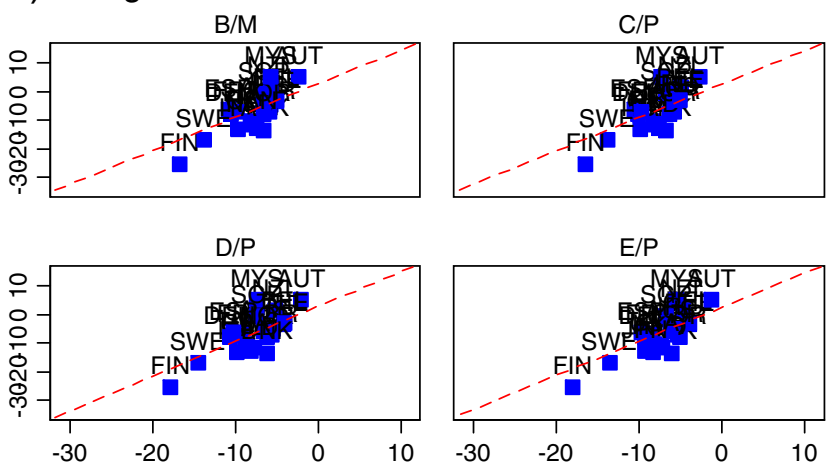

d) Using Regional Portfolios in ICAPM
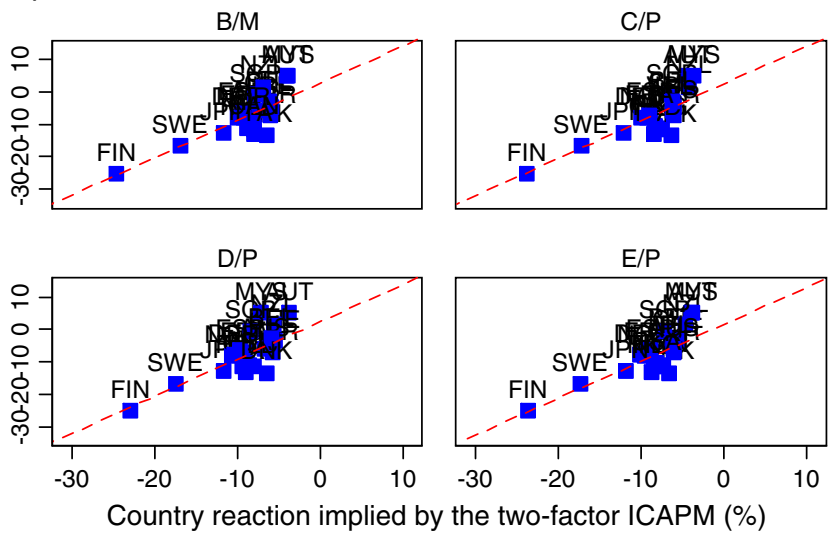
$\widetilde{e}_{d, t+1}$, will lower the current excess equity return. In contrast, news about a downward revision of expected future excess return, $\widetilde{e}_{e, t+1}$, or news about negative revisions to future real interest rate expectation, $\widetilde{e}_{r, t+1}$, will increase the current excess equity return.

A corresponding dissection of international equity returns is similar, with an addition of the real exchange rate

$\widetilde{e}_{t+1}^{*}=\left(E_{t+1}-E_{t}\right)\left\{\sum_{j=0}^{\infty}\left(\rho^{*}\right)^{j} \Delta d_{t+1+j}^{*}-\sum_{j=0}^{\infty}\left(\rho^{*}\right)^{j} \Delta r_{t+1+j}^{*}-\sum_{j=0}^{\infty}\left(\rho^{*}\right)^{j} \Delta e_{t+1+j}^{*}\right\}$,

where the asterisk $\left({ }^{*}\right)$ superscripts denote international variables. The excess of the international equity return (expressed in dollars) over the U.S. Treasury bill return is

$f_{t+1}=e_{t+1}^{*}-\Delta q_{t+1}+r_{t+1}^{*}-r_{t+1}$,

where $f$ is the international excess equity return and $q$ is the real exchange value of the local currency (an increase in $q$ is the dollar's real appreciation against the local currency). The innovation in the international excess equity return is

$$
\begin{aligned}
\tilde{f}_{t+1}= & \left(E_{t+1}-E_{t}\right) \\
& \left\{\sum_{j=0}^{\infty}\left(\rho^{*}\right)^{j} \Delta d_{t+1+j}^{*}-\sum_{j=0}^{\infty}\left(\rho^{*}\right)^{j} \Delta r_{t+1+j}-\sum_{j=0}^{\infty}\left(\rho^{*}\right)^{j} \Delta f_{t+1+j}-\sum_{j=0}^{\infty}\left(\rho^{*}\right)^{j} \Delta q_{t+1+j}\right\},
\end{aligned}
$$

which can be rewritten as

$\widetilde{f}_{t+1}=\widetilde{f}_{d, t+1}-\widetilde{f}_{r, t+1}-\widetilde{f}_{f, t+1}-\widetilde{f}_{q, t+1}$.

The rationale for the signs on $\widetilde{f}_{d, t+1}, \widetilde{f}_{r, t+1}, \widetilde{f}_{f, t+1}$ is the same as those for the signs on the U.S. equation. For $\widetilde{f}_{q . t+1}$, news that the U.S. dollar will appreciate reduces the expected dollar returns on international equities. Without any revision in other components of return innovation, the current excess equity return in the international markets will have to drop, so that higher future returns can be generated from the same cash flow. ${ }^{9}$

We can write the variance of the U.S. current excess equity return innovation as

$$
\begin{aligned}
\operatorname{var}(\widetilde{e})= & \operatorname{var}\left(\widetilde{e}_{d}\right)+\operatorname{var}\left(\widetilde{e}_{r}\right)+\operatorname{var}\left(\widetilde{e}_{e}\right) \\
& -2 \operatorname{cov}\left(\widetilde{e}_{d}, \widetilde{e}_{e}\right)-2 \operatorname{cov}\left(\widetilde{e}_{d}, \widetilde{e}_{e}\right)+2 \operatorname{cov}\left(\widetilde{e}_{r}, \widetilde{e}_{e}\right) .
\end{aligned}
$$

The variance of the international current excess equity return innovation can be decomposed into ten components as

$$
\begin{aligned}
\operatorname{var}(\widetilde{f})= & \operatorname{var}\left(\widetilde{f}_{d}\right)+\operatorname{var}\left(\widetilde{f}_{r}\right)+\operatorname{var}\left(\widetilde{f}_{f}\right)+\operatorname{var}\left(\widetilde{f}_{q}\right) \\
& -2 \operatorname{cov}\left(\widetilde{f}_{d}, \widetilde{f}_{r}\right)-2 \operatorname{cov}\left(\widetilde{f}_{d}, \widetilde{f}_{f}\right)-2 \operatorname{cov}\left(\widetilde{f}_{d}, \widetilde{f}_{q}\right) \\
& +2 \operatorname{cov}\left(\widetilde{f}_{r}, \widetilde{f}_{f}\right)+2 \operatorname{cov}\left(\widetilde{f}_{r}, \widetilde{f}_{q}\right)+2 \operatorname{cov}\left(\widetilde{f}_{f}, \widetilde{f}_{q}\right) .
\end{aligned}
$$

To obtain proxies for the revisions in expectations, we estimate the first-order VAR in nine variables, including:

- Excess return on U.S. equities (e) and International equities ( $f$ ): calculated as total dollar returns minus the risk-free rate (1-month U.S. Treasury bill yield); source: equity returns of the market and portfolios formed on value-growth premia from the Fama-French database.

- U.S. real interest rates $(r)$ : calculated as the 1-month Treasury bill rate minus the log difference in the nonseasonally-adjusted CPI; source: CPI data from the International Financial Statistics (IFS) and Datastream.

- U.S. real exchange rate $(q)$ : calculated as the log difference in the foreign currency value of U.S. dollar plus the log difference in the nonseasonally-adjusted U.S. CPI, minus the log difference in the nonseasonally-adjusted $\mathrm{CPI}$; source: nominal exchange rate data from IFS. Euro currency applies to Austria, Belgium, Germany, Spain, Finland, France, Ireland, Italy, and Netherlands starting January 1999.

- Change in the U.S. nominal interest rates $(\Delta i)$ : calculated as the change in the 3-month bill rate; source: the Federal Reserve.

- U.S. term spread (s): calculated as the difference between the 10-year and 1-month U.S. Treasury yields; source: the 10-year Treasury constant maturity series from the U.S. Treasury.

- Relative U.S. Treasury bill rate ( $r b$ ): calculated as the 3-month bill rate minus its 12-month lagged moving average

- U.S. equity dividend yield $(d y)$ and International equity dividend yield $\left(d y^{*}\right)$ : calculated as the sum of dividends over the last twelve months divided by the current price; source: CRSP.

We can write the VAR system as

$z_{t+1}=A z_{t}+w_{t+1}$

where $z_{t+1}$ is $n p \times 1$ vector containing the excess equity return, the real interest rate, and additional variables. ${ }^{10}$

$z=\left[e, f, r, q, \Delta i, s, r b, d y, d y^{*}\right]^{\prime}$

\footnotetext{
${ }^{9}$ Hau and Rey (2006) find that returns on the foreign currency are negatively correlated with excess returns on foreign over U.S. equity, and positively correlated with equity flows into the foreign market. They argue that these resultant correlations of portfolio balancing (uncovered equity parity) are important to the joint determination of exchange rates, equity prices, and capital flows.

${ }^{10}$ Note that the rationale for the inclusion of the change in the nominal interest rate differs from the inclusion of the real interest rate in the VAR analysis. For the inclusion of real interest rates, the rationale originated from Campbell and Shiller (1988) a VAR framework, which shows that from the simple growth model by Gordon (1962), the dividend-price ratio is related to, and can be derived as, a present value of expected one-period interest rates and dividend-growth rates. For the inclusion of nominal interest rates, studies starting with Ferson and Harvey (1991), Fama and French (1988), and Keim and Stambaugh (1986) have found that nominal interest rates have significant forecasting power for the stock returns. Subsequent studies, including, for example, Bernanke and Kuttner (2005) on stock returns and monetary policy, and Ammer and Mei (1996) on variance decomposition of international stock market returns, have also included both the change in the nominal interest rate and real interest rate.

Fig. 1. a. Empirical responses of country returns to unexpected movement of oil prices and international two-factor asset-pricing model. All returns are monthly in dollars. The figure depicts the responses of the MSCI country portfolios (Fama-French) to an unexpected increase of oil prices by one dollar per barrel over the sample period given in the column headings. The vertical axis values are the fitted country portfolio's return responses. The values on the horizontal axis are the country portfolio's return responses implied by the international two-factor (one-state-variable) ICAPM using the global portfolio (top row) and the regional portfolios (bottom row). The difference between the high- and low B/M (E/P,C/P,D/P) portfolio returns is the second explanatory return in the one-state-variable ICAPM. The dash line is $45^{\circ}$. The sample period is May 1989 to December 2006 . b. Empirical responses of country returns to unexpected movement of Federal funds rates and international two-factor asset-pricing model. All returns are monthly in dollars. The figure depicts the responses of the MSCI country portfolios (Fama-French) to an unexpected increase of Federal funds rate by one hundred basis points over the sample period given in the column headings. The vertical axis values are the fitted country portfolio's return responses. The values on the horizontal axis are the country portfolio's return responses implied by the international two-factor (one-state-variable) ICAPM using the global portfolio (top row) and the regional portfolios (bottom row). The difference between the high- and low B/M (E/P,C/P,D/P) portfolio returns is the second explanatory return in the one-state-variable ICAPM. The dash line is $45^{\circ}$. The sample period is May 1989 to December 2006.
} 


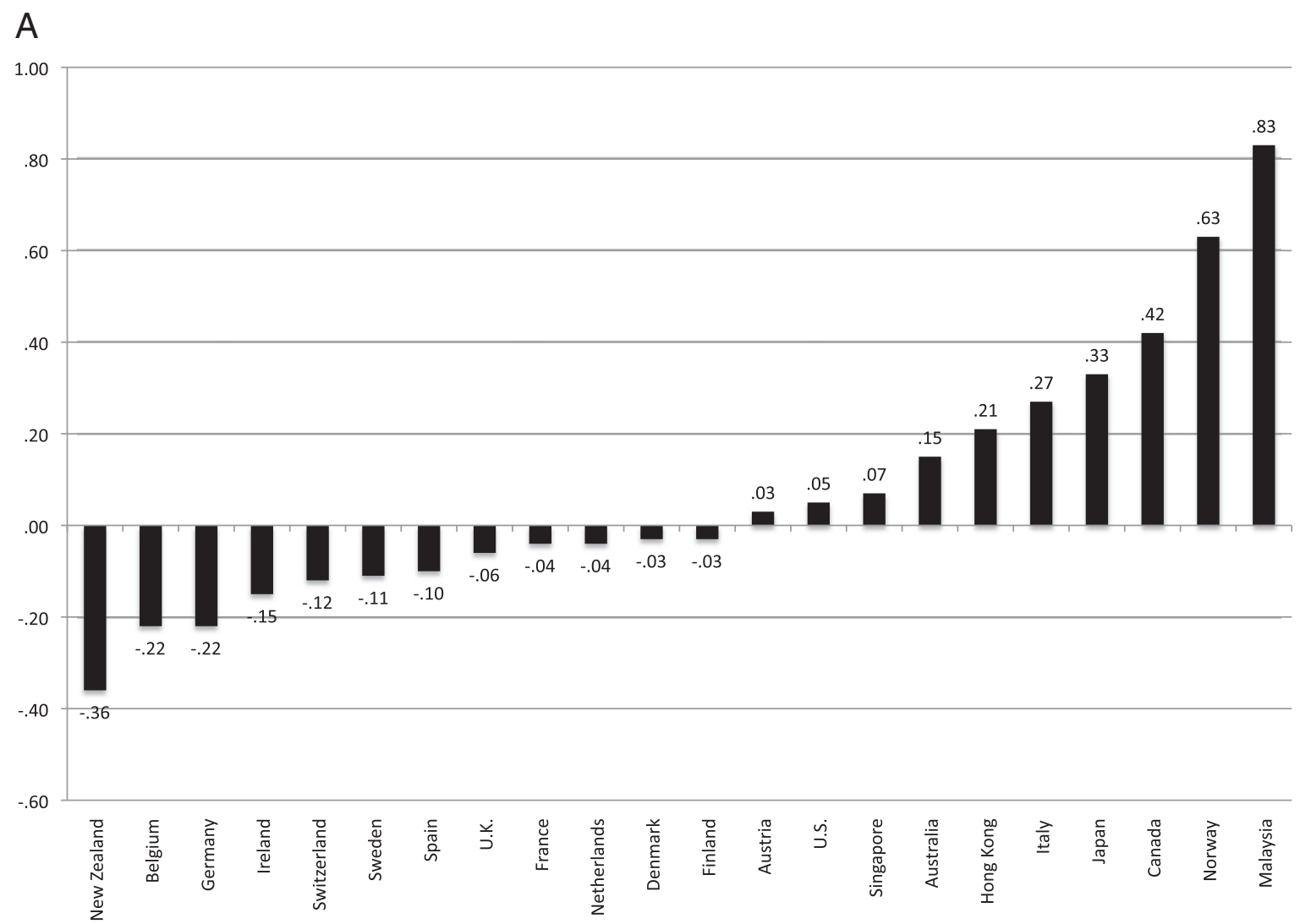

B

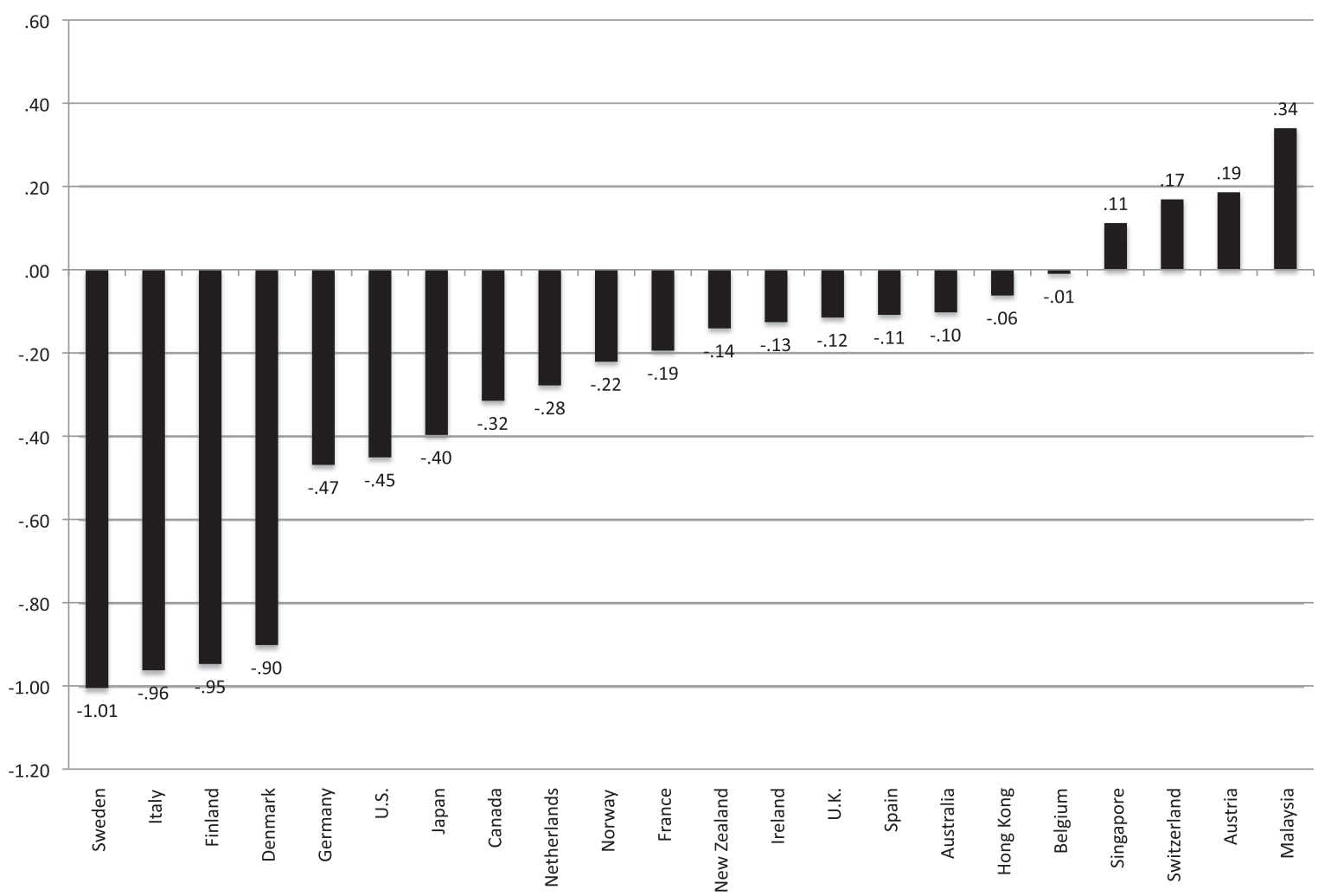

Fig. 2. A. The response of current excess return innovation to oil prices. The figure provides the effects of oil prices (one dollar per barrel increase) on the current excess equity returns. The nine-variable first-order VAR is estimated over the entire sample from May 1989 to December 2006, and the responses are reported for the period of February 1994 to December 2006. B. The response of current excess return innovation to funds rates. The figure provides the effects of Federal Reserve funds rates (five basis points increase) on the current excess equity returns. The nine-variable first-order VAR is estimated over the entire sample from May 1989 to December 2006 , and the responses are reported for the period of February 1994 to December 2006. 
Table 2

Economic integration and the responses of international equity returns to oil prices and Federal Reserve funds rates. The table reports coefficient estimates from the regressions measuring the effects of oil price and funds rate shocks on the excess equity returns, the discounted sums of current and future dividends, current and future real interest rates, and future excess equity returns news. The gravity-method trade integration is bilateral trade flows to GDP, instrumented by distance, similarity of population size and land area, common language, common land border, and landlocked indicator. The gravity-method financial integration is bilateral equity flows to market capitalization, instrumented by sophistication of financial markets, distance, telephone volume, number of bank subsidiaries, and the degree of insider trading. The correlation indicator of trade integration is the comovement between future U.S. dividend innovation, $e_{d}$ and future international dividend innovation, $f_{d} ;$ the correlation indicator of finance integration is the comovement between future U.S. expected return innovations, $e_{e}$, and future international expected return innovation, $f_{f}$. The estimation pools the market, high book to market value portfolio, and low book to market value portfolios of all countries. The regressions also include an intercept and dummy variables for high value and high growth portfolios, whose estimates are not reported. The heteroscedasticity robust standard errors are in the bracket. $\left.{ }^{* * * * *}\right)$ signifies statistical significance at a 10(5,1) percent level. The sample period is May 1989-December 2006, and includes countries with both measures of trade and financial integration: Australia, Switzerland, Germany, Spain, France, United Kingdom, Hong Kong, Italy, Japan, Netherlands, Singapore, and Sweden.

\begin{tabular}{|c|c|c|c|c|c|c|c|c|}
\hline \multirow{2}{*}{$\frac{\text { Integration: }}{\text { Shocks: }}$} & \multicolumn{4}{|c|}{ Gravity method } & \multicolumn{4}{|c|}{ Correlation indicator } \\
\hline & Oil price & & Funds rate & & Oil price & & Funds rate & \\
\hline \multicolumn{9}{|c|}{ Response of current excess return innovation } \\
\hline Trade & .11 & {$[.03]^{* * *}$} & -4.56 & {$[1.55]^{* * *}$} & -1.06 & {$[.34]^{* * *}$} & -11.85 & {$[15.44]$} \\
\hline Finance & -.17 & {$[.06]^{* * *}$} & 10.90 & {$[2.35]^{* * *}$} & -.09 & {$[.52]$} & 47.03 & {$[19.31]^{* *}$} \\
\hline$R^{2}$ & .31 & & .29 & & .60 & & .15 & \\
\hline \multicolumn{9}{|c|}{ Response of dividend news } \\
\hline Trade & .04 & {$[.02]^{* *}$} & -2.59 & {$[1.15]^{* *}$} & -.36 & {$[.25]$} & -7.86 & {$[12.10]$} \\
\hline Finance & -.05 & {$[.04]$} & 7.57 & {$[1.71]^{* * *}$} & .03 & {$[.37]$} & 25.31 & {$[14.45]^{*}$} \\
\hline$R^{2}$ & .31 & & .27 & & .38 & & .08 & \\
\hline \multicolumn{9}{|c|}{ Response of discount rate news } \\
\hline Trade & -.10 & {$[.02]^{* * *}$} & -.49 & {$[1.02]$} & -.63 & {$[.40]$} & -11.72 & [11.79] \\
\hline Finance & .35 & {$[.05]^{* * *}$} & -2.74 & {$[1.29]^{* *}$} & 1.93 & {$[.51]^{* * *}$} & 8.11 & {$[17.07]$} \\
\hline$R^{2}$ & .54 & & .37 & & .38 & & .33 & \\
\hline \multicolumn{9}{|c|}{ Response of future excess return news } \\
\hline Trade & -.06 & {$[.02]^{* * *}$} & 1.97 & {$[0.50]^{* * *}$} & .70 & {$[.13]^{* * *}$} & 4.11 & [4.88] \\
\hline Finance & .11 & {$[.03]^{* * *}$} & -3.30 & {$[0.78]^{* * *}$} & .10 & {$[.19]$} & -21.80 & {$[8.04]^{* *}$} \\
\hline$R^{2}$ & .24 & & .25 & & .72 & & .25 & \\
\hline
\end{tabular}

Let $t_{1}$ denote a vector whose first element is one and whose other elements are zero, so that $\iota_{1}^{\prime} z=$ e. $t_{2} \ldots t_{9}$ are similarly defined. It follows that the news components of the U.S. and international excess equity returns can be written as

$$
\begin{array}{ll}
\widetilde{e}_{t+1}=\iota_{1}^{\prime} w_{t+1} & \widetilde{f}_{t+1}=\iota_{2}^{\prime} w_{t+1} \\
\widetilde{e}_{e, t+1}=\iota_{1}^{\prime} \rho A\left(I-\rho^{*} A\right)^{-1} w_{t+1} & \widetilde{f}_{f, t+1}=\iota_{2} \rho^{*} A\left(I-\rho^{*} A\right)^{-1} w_{t+1} \\
\widetilde{e}_{r, t+1}=\iota_{3}^{\prime}\left(I-\rho^{*} A\right)^{-1} w_{t+1} & \widetilde{f}_{r, t+1}=\iota_{3}^{\prime}\left(I-\rho^{*} A\right)^{-1} w_{t+1} \\
\widetilde{e}_{d, t+1}=\widetilde{e}_{t+1}-\widetilde{e}_{r, t+1}-\widetilde{e}_{e, t+1} & \widetilde{f}_{q, t+1}=\iota_{4}^{\prime}\left(1-\rho^{*}\right)\left(I-\rho^{*} A\right)^{-1} w_{t+1} \\
& \widetilde{f}_{d, t+1}=\widetilde{f}_{t+1}-\widetilde{f}_{r, t+1}-\widetilde{f}_{f, t+1}-\widetilde{f}_{q, t+1}
\end{array}
$$

We conduct the decomposition for two sample periods, before and after February 1994. The nine components (six for U.S. return news) of international excess equity return innovations are calculated as a percentage of the total variance. The variables are made stationary and have zero means for the VAR. Similar to the previous studies, we find that the variance of the equity premium (expected future excess return) accounts for most of the total variance of equity markets in the U.S. (Bernanke \& Kuttner, 2005) and the U.K. (Ammer \& Mei, 1996). The real interest rate news and the real exchange rate news have insignificant contribution to the current excess equity returns across the global markets and in both sub-samples. Specifically, the variance of dividend news accounts for approximately $20 \%$ of the total current excess return innovation, and the variance of future excess return accounts for $50 \%$.

Next, if we include as exogenous variable the unexpected component $\left(\bar{\Delta} s^{u}\right)$ of oil price and Federal funds rate, then the first-order VAR is

$z_{t+1}=A z_{t}+\phi \bar{\Delta} s_{t+1}^{u}+w_{t+1}^{\perp}$

where $\phi$ is an $n \times 1$ vector representing the contemporaneous reaction of the elements of $z_{t+1}$ to the change period $t+1$. The new disturbance term $w_{t+1}^{\perp}$ is orthogonal to the oil and funds rate surprises. This equation breaks the VAR's 1-month-ahead forecast error into a component capturing news about oil price and Fed policy, $\phi \bar{\Delta} s_{t+1}^{u}$, and a component incorporating information about factors other than the oil price and Fed policy change. Following Bernanke and Kuttner (2005), we use a two-step procedure to obtain the VAR parameters $A$ and then regress the VAR one-step forecast errors on the unexpected component of oil price, $\bar{\Delta} o^{u}$, and Federal Funds rate, $\bar{\Delta} i^{u}$. This procedure allows for the estimation of VAR dynamics over a sample longer than the period for which the data on the oil price and Fed policy shocks are available. We use the estimated $\phi$ of the post 1994 sub-sample to minimize the possibility of contemporaneous response of the Federal funds rate surprises to other macroeconomic news.

We can write the U.S. excess return innovation in terms of the VAR coefficients

$$
\begin{aligned}
e_{e, t+1} & =\iota_{1}^{\prime} \rho A(I-\rho A)^{-1} w_{t+1} \\
& =\iota_{1}^{\prime} \rho A(I-\rho A)^{-1}\left(\phi \bar{\Delta} s_{t+1}^{u}+w_{t+1}^{\perp}\right) .
\end{aligned}
$$

The response of the present value of expected future excess returns to oil price and funds rate shocks is

$\iota_{1} \rho A(I-\rho A)^{-1} \phi$

with the response of the present value of current and expected future real interest returns:

$\iota_{3}^{\prime}(I-\rho A)^{-1} \phi$

and the implied response of the present value of current and expected future dividends:

$\iota_{1}^{\prime} \phi+\iota_{1}^{\prime} \rho A(I-\rho A)^{-1} \phi+\iota_{3}^{\prime}(I-\rho A)^{-1} \phi=\left(\iota_{1}^{\prime}+\iota_{3}^{\prime}\right)(I-\rho A)^{-1} \phi$. 
Similarly, for the international excess returns

$$
\begin{aligned}
f_{f, t+1} & =\iota_{2}^{\prime} \rho^{*} A\left(I-\rho^{*} A\right)^{-1} w_{t+1} \\
& =\iota_{2} \rho^{*} A\left(I-\rho^{*} A\right)^{-1}\left(\phi \bar{\Delta} s_{t+1}^{u}+w_{t+1}^{\perp}\right),
\end{aligned}
$$

with the response of the present value of expected future excess returns:

$\iota_{2}^{\prime} \rho^{*} A\left(I-\rho^{*} A\right)^{-1} \phi$

the response of the present value of current and expected future real interest returns:

$\iota_{3}^{\prime}\left(I-\rho^{*} A\right)^{-1} \phi$,

the response of the present value of current and expected future real exchange rate returns:

$\iota_{4}\left(1-\rho^{*}\right)\left(I-\rho^{*} A\right)^{-1} \phi$,

and the implied response of the present value of current and expected future dividends:

$\left[\iota_{2}^{\prime}+\iota_{3}^{\prime}+\iota_{4}^{\prime}\left(1-\rho^{*}\right)\right](I-\rho A)^{-1} \phi$

The response of each country portfolio displays a wide variation on the impact of oil prices and funds rates on the revisions in current excess returns, and corresponding expectation of dividends, real interest rates, and expected future returns. Fig. $2 \mathrm{~A}$ and B plots the responses of current excess return innovation to oil prices and to funds rates, respectively. The nine-variable first-order VAR is estimated over the entire sample, and the responses are calculated for the period of February 1994 to December 2006. Fig. 2A shows that the effects of oil prices (one dollar per barrel increase) on the current excess equity returns vary across countries, ranging from.36 to.83\% return adjustment. While the effects are unexpectedly positive for several countries, some of these countries may benefit from the energy price increase, i.e. Singapore, Malaysia, and Norway. Fig. 2B shows that the effects of funds rates (five basis point increase) are negative for the majority of countries, except for a few small countries.

\subsection{Economic integration and the empirical responses of equity returns to global shocks}

Our findings so far suggest that international equity returns respond to oil prices and funds rates to a varying degree across countries. To further understand the interactions between the national markets, we estimate the extent of economic integration using the U.S. as a benchmark. We use a gravity-instrumented methodology to extract the size of economic integration. This gravity methodology employs countries' geographic (i.e. distance, common land border, size and output similarity) and informational (e.g., telephone volume, common language, sophistication of financial markets, number of bank subsidiaries) variables to correct endogeneity issues, and therefore yields a superior measure of economic integration to the de facto measures, i.e. bilateral trade to GDP and bilateral equity flows to market capitalization.

We use the gravity method to estimate the trade integration similar to that in Frankel and Romer (1999) and Frankel and Rose (2002), and the finance integration similar to that in Aviat and Coeurdacier (2007) and Portes and Rey (2005), to account for the integration between a country and the U.S. We also examine an alternative measure of trade and finance integration derived from covariance decomposition of excess equity returns (Ammer and Mei (1996)). Using this second approach, we obtain the correlation indicator of trade integration, measured as the comovement between future U.S. dividend innovation, $e_{d}$, and future international dividend innovation, $f_{d}$; the financial integration is measured as the comovement between future U.S. expected return innovations, $e_{e}$, and future international expected return innovation, $f_{f .}{ }^{11}$

To estimate the association between economic integration and the responses of equity returns to economic shocks, we include countries with both measures of trade and financial integration: Australia, Switzerland, Germany, Spain, France, United Kingdom, Hong Kong, Italy, Japan, Netherlands, Singapore, Sweden. We report in Table 2 the regressions of the responses of equity returns as the dependent variable, and the measures of trade and finance integration as the explanatory variables. ${ }^{12}$ The estimation is done for the responses of current excess returns, dividend news, discount rate news, and future return news, using both measures of economic integration: the gravity method and the correlation linkages.

For the responses to the oil price shocks, the gravity trade (finance) integration increases (decreases) the responses of current returns and dividend news; the opposite applies for the responses of discount rate and future return news. A one-percentage point increase of trade integration between a country and the U.S. is associated with a higher response of current excess returns by .11\% and a higher response of dividend news by $.04 \%$, whereas it is negatively associated with a lower response of discount rate news by $-.10 \%$ and future return news by $-.06 \%$. A onepercentage point increase of finance integration lowers the response of current excess returns by $-.17 \%$, whereas it raises the response of discount rate news by $.35 \%$ and of future return news by $.11 \%$.

For the responses to the fund rate shocks, the gravity trade (finance) integration decreases (increases) the responses of current returns and dividend news; the opposite applies for the responses of discount rate and of future return news. A one-percentage point increase of trade integration between a country and the U.S. lowers the response of current excess returns by $-4.56 \%$ and of dividend news by $-2.59 \%$, whereas it raises the response of future return news by $1.97 \%$. A one-percentage point increase of finance integration raises the response of current excess returns by $10.90 \%$ and of dividend news by $7.57 \%$, whereas it lowers the response of discount rate news by $-2.74 \%$ and of future return news by $-3.30 \%{ }^{13}$

To sum up, trade integration increases the responses of international equity returns to oil prices, while finance integration increases the responses to funds rates. Comparing between the gravity measure and the correlation indicator of economic integration, the coefficient estimates from the regressions using the gravity-instrumented integration are sharper than those from the regressions using the correlation indicators. Since an unexpected movement of the oil prices is a world-wide event, the response of international equity returns may be more correlated than the response to the funds rate shocks. Therefore, the gravityinstrumented integration should be more exogenous to the error term in the estimation relative to the economic integration measured by the correlation indicators.

These findings are related to at least two strands of recent empirical studies on the global equity markets and economic integration. Hausman and Wongswan (2006) find that a cross-country variation in the equity market response to Federal Reserve announcement is strongly related to the percentage of each country's equity market capitalization owned by U.S. investors. Lane and Milesi-Ferretti (2008) find in a cross-country data that larger bilateral financial positions are associated

\footnotetext{
11 The correlation of gravity measure and correlation indicator is - . 16 for trade integration and .33 for financial integration.

12 We also include a constant and a dummy variable for the value and for the growth portfolios to account for asset-pricing factors (coefficient not reported).

${ }^{13}$ As an additional check, we also examine the effect of the oil price shocks on the value portfolios $(\mathrm{B} / \mathrm{M})$ : the association with the current excess returns is $-.12 \%$ and with dividend news is $-.10 \%$. An unexpected oil price increase may in general increase the outlook for world-wide economic boom, and thus a higher demand for growth portfolios. The effect of the funds rate shocks on the discount rate news for the value portfolios is positive and larger, an evidence supportive to the hypothesis that financial friction is associated with a higher response of equity returns. This finding is robust to other measures of value, including $\mathrm{E} / \mathrm{P}, \mathrm{C} / \mathrm{P}$, and $\mathrm{D} / \mathrm{P}$.
} 
with more correlated stockmarket returns. The findings in this paper are also related to Guidolin and Timmermann (2008b) where the presence of regimes in the return distribution is leading to a large increase in U.S. investor's optimal holdings of U.S. stocks, and thus an explanation of the strong home bias observed in U.S. investors' asset allocation. This paper contributes to the literature by considering jointly the effects of oil prices and Federal Reserve funds rates, as well as highlighting the caveat of using the gravity-instrumented economic integration versus other de facto and correlation indicators.

\section{Concluding remarks}

This paper reports the responses of international equity returns to oil prices and Federal Reserve funds rates, and new evidence that economic integration has explanatory power on the international responses of asset prices to global shocks. We provide empirical findings in an integrated methodological approach, linking international asset-pricing model, variance decomposition, and cross-country estimation. The paper contributes to the strand of the literature that attempts to understand the globalization and risk-sharing factors via cross-border trade and capital flow models. Our main findings suggest that higher gravity-instrumented trade (finance) integration is positively associated with the empirical response of the current excess equity returns to the oil price shocks (to the funds rate shocks). We also find that the estimation using a gravity-instrumented trade and finance integration yields different results, both quantitatively and qualitatively, from those using the de facto (bilateral trade and financial flows divided by GDP) and the correlation indicator between national markets.

\section{References}

Albuquerque, Rui, \& Vega, Clara (2007). Economic news and international stock market co-movement. Board of governors of the Federal Reserve system.

Alquist, Ron, \& Kilian, Lutz (2010). What do we learn from the price of oil futures? Journal of Applied Econometrics, 25(4), 539-573.

Ammer, John, \& Mei, Jianping (1996). Measuring international economic linkages with stock market data. Journal of Finance, 51(5), 1743-1763.

Ammer, John, \& Wongswan, Jon (2007). Cash flows and discount rates, industry and country effects and co-movement in stock returns. The Financial Review, 42(2), 211-226.

Andersen, Torben G., Bollerslev, Tim, Diebold, Francis X., \& Vega, Clara (2007). Real-time price discovery in global stock, bond and foreign exchange markets. Journal of International Economics, 73(2), 251-277.

Andersson, Magnus (2007). Using intraday data to gauge financial market responses to fed and ecb monetary policy decisions. ECB working paper series no. 726 .

Aviat, Antonin, \& Coeurdacier, Nicolas (2007). The geography of trade in goods and asset holdings. Journal of International Economics, 71(1), 22-51.

Beaudry, Paul, \& Portier, Franck (2006). Stock prices, news and economic fluctuations. American Economic Review, 96(4), 1293-1307.

Bergin, Paul R., \& Jorda, Oscar (2004). Measuring monetary policy interdependence. Journal of International Money and Finance, 23(5), 761-783.

Bernanke, Ben S., \& Gertler, Mark (2001). "Should central banks respond to movements in asset prices?". The American Economic Review, 91(2), 253-257.

Bernanke, Ben S., Gertler, Mark, \& Watson, Mark (1997). Systematic monetary policy and the effects of oil price shocks. Brookings Papers on Economic Activity, 1997(1), 91-157.

Bernanke, Ben S., Gertler, Mark, \& Watson, Mark (2004). "Oil shocks and aggregate macroeconomic behavior: The role of monetary policy: A reply”. Journal of Money, Credit, and Banking, 36(2), 287-291.

Bernanke, Ben S., \& Kuttner, Kenneth N. (2005). What explains the stock market's reaction to Federal Reserve policy? Journal of Finance, 60(3), 1221-1257.

Campbell, John Y., \& Ammer, John (1993). What moves the stock and bond markets? A variance decomposition for long-term asset returns. Journal of Finance, 48(1), 3-37.

Campbell, John Y., \& Shiller, Robert J. (1988). Stock prices, earnings, and expected dividends. Journal of Finance, 43(3), 661-676.

Carlstrom, Charles T., \& Fuerst, Timothy Stephen (2006). Oil prices, monetary policy, and counterfactual experiments. Journal of Money, Credit, and Banking, 38(7), 1945-1958.

Cavallo, Michele, \& Wu, Tao (2006). Measuring oil-price shocks using market-based information. Federal Reserve Bank of San Francisco Working Paper 2006-28.

Chen, Shiu-Sheng (2007). Does monetary policy have asymmetric effects on stock returns? Journal of Money, Credit, and Banking, 39(2-3), 667-688.

Coeurdacier, Nicolas, Kollmann, Robert, \& Martin, Philippe (2007). International portfolios with supply, demand and redistributive shocks. : London Business School.

Conover, C. Mitchell, Jensen, Gerald R., \& Johnson, Robert R. (1999). Monetary environments and international stock returns. Journal of Banking E Finance, 23(9), 1357-1381.

Cooley, Thomas F., \& Quadrini, Vincenzo (2003). Common currencies vs. monetary independence. Review of Economic Studies, 70(4), 785-806.

Craine, Roger, \& Martin, Vance L. (2008). International monetary surprise spillovers. Journal of International Economics, 75(1), 180-196.
Davig, Troy, \& Gerlach, Jeffrey R. (2006). State-dependent stock market reactions to monetary policy. International Journal of Central Banking, 2(4), 65-83.

Di Giorgio, Giorgio, \& Nistico, Salvatore (2007). Monetary policy and stock prices in an open economy. Journal of Money, Credit, and Banking, 39(8), 1947-1985.

Ehrmann, Michael, \& Fratzscher, Marcel (2004). Taking stock: Monetary policy transmission to equity markets. Journal of Money, Credit, and Banking, 36(4), 719-737.

Ehrmann, Michael, \& Fratzscher, Marcel (2006). Global financial transmission of monetary policy shocks. CESifo working paper no. 1710.

Ehrmann, Michael, \& Fratzscher, Marcel (2007). Communication by central bank committee members: Different strategies, same effectiveness? Journal of Money, Credit, and Banking, 39(2-3), 509-541.

Fama, Eugene F., \& French, Kenneth R. (1988). Dividend yields and expected stock returns. Journal of Financial Economics, 22(1), 3-25.

Fama, Eugene F., \& French, Kenneth R. (1998). Value versus growth: The international evidence. Journal of Finance, 53(6), 1975-1999.

Ferson, Wayne E., \& Harvey, Campbell R. (1991). The variation of economic risk premiums. Journal of Political Economy, 99(2), 385-415.

Forbes, Kristin J., \& Chinn, Menzie D. (2004). A decomposition of global linkages in financial markets over time. The Review of Economics and Statistics, 86(3), 705-722.

Forbes, Kristin J., \& Rigobon, Roberto (2002). No contagion, only interdependence: Measuring stock market comovements. Journal of Finance, 57(5), 2223-2261.

Frankel, Jeffrey A., \& Romer, David (1999). Does trade cause growth? American Economic Review, 89(3), 379-399.

Frankel, Jeffrey, \& Rose, Andrew (2002). An estimate of the effect of common currencies on trade and income. Quarterly Journal of Economics, 437-466.

Gordon, Myron J. (1962). The investment financing, and valuation of the corporation. Homewood, IL: R.D. Irwin.

Gosselin, Pierre, Lotz, Aileen, \& Wyplosz, Charles (2007). Should central banks reveal expected future interest rates? Geneva: Graduate Institute of International Studies.

Guidolin, Massimo, \& Timmermann, Allan (2008b). Size and value anomalies under regime shifts. Journal of Financial Economics, 6(1), 1-48.

Gurkaynak, Refet, Sack, Brian, \& Swanson, Eric (2005). Do actions speak louder than words? The response of asset prices to monetary policy actions and statements. International Journal of Central Banking, 1(1), 55-93.

Hamilton, James D. (2003). What is an oil shock? Journal of Econometrics, 113, 363-398.

Hamilton, James Douglas, \& Herrera, Ana Maria (2004). Oil shocks and aggregate macroeconomic behavior: The role of monetary policy: a comment. Journal of Money, Credit, and Banking, 36(2), 265-286.

Hau, Harald, \& Rey, Helene (2006). Exchange rates, equity prices, and capital flows. Review of Financial Studies, 19(1), 273-317.

Hausman, Joshua, \& Wongswan, Jon (2006). Global asset prices and FOMC announcements. Board of governors of the Federal Reserve system, international finance discussion papers no. 886 .

Imbs, Jean (2004). Trade, finance, specialization, and synchronization. The Review of Economics and Statistics, 86(3), 723-734.

Jones, Charles M., \& Kaul, Gautam (1996). Oil and the stock markets. Journal of Finance, 51(2), 463-491.

Keim, Donald B., \& Stambaugh, Robert F. (1986). Predicting returns in the stock and bond markets. Journal of Financial Economics, 17(2), 357-390.

Kilian, Lutz, \& Park, Cheolbeom (2009). The impact of oil price shocks on the U.S. stock market. International Economic Review, 50(4), 1267-1287.

Kuttner, Kenneth N. (2001). Monetary policy surprises and interest rates: Evidence from the Fed funds futures market. Journal of Monetary Economics, 47(3), 523-544.

Lane, Philip R., \& Milesi-Ferretti, Gian Maria (2008). International Investment Patterns. The review of economics and statistics, 90(3), 538-549.

Leduc, Sylvain, \& Sill, Keith (2004). A quantitative analysis of oil-price shocks, systematic monetary policy, and economic downturns. Journal of Monetary Economics, 51(4), 781-808.

Pappa, Evi (2004). Do the ECB and the Fed really need to cooperate? Optimal monetary policy in a two-country world. Journal of Monetary Economics, 51(4), 753-779.

Patelis, Alex D. (1997). Stock return predictability and the role of monetary policy. Journal of Finance, 52(5), 1951-1972.

Piazzesi, Monika, \& Swanson, Eric (2008). Futures prices as risk-adjusted forecasts of monetary policy. Journal of Monetary Economics, 55(4), 677-691.

Portes, Richard, \& Rey, Hélène (2005). The determinants of cross-border equity flows. Journal of International Economics, 65(2), 269-296.

Rigobon, Roberto, \& Sack, Brian (2003). Measuring the reaction of monetary policy to the stock market. Quarterly Journal of Economics, 118(2), 639-669.

Rigobon, Roberto, \& Sack, Brian (2004). The impact of monetary policy on asset prices. Journal of Monetary Economics, 51(8), 1553-1575.

Romer, Christina D., \& Romer, David H. (2004). A new measure of monetary shocks: Derivation and implications. American Economic Review, 94(4), 1055-1084.

Scotti, Chiara (2006). A bivariate model of Fed and ECB main policy rates. Board of Governors of the Federal Reserve System, International Finance Discussion Papers, No. 875.

Taylor, John B. (2007). The importance of being predictable. Remarks prepared for the policy panel on "monetary policy under uncertainty." 23rd annual policy conference. Federal Reserve Bank of St. Louis.

Thorbecke, Willem (1997). On stock market returns and monetary policy. Journal of Finance, 52(2), 635-654.

Wongswan, Jon (2009). The Response of global equity indexes to U.S. monetary policy announcements. Journal of International Money and Finance, 28(2), 344-365.

Woodford, Michael (2005). Central bank communication and policy effectiveness. Federal Reserve Bank of Kansas City.

Wu, Tao, \& McCallum, Andrew (2005). Do oil futures prices help predict future oil prices? FRBSF Economic Letter, 38, 1-3. 